\title{
A Research about the Level of Using Language Teaching Methods and Its Effect on Some Variables: in Turkey
}

\author{
Burcu Okmen *, Abdurrahman Kilic \\ Department of Educational Sciences, Duzce University, Turkey \\ *Corresponding Author:burcuokmen91@hotmail.com
}

Copyright $(02016$ by authors, all rights reserved. Authors agree that this article remains permanently open access under the terms of the Creative Commons Attribution License 4.0 International License.

\begin{abstract}
The aim of this research is to define language teaching methods used by English teachers in Turkey and their usage level and to define if the level of usage changes according to gender, seniority and graduated school types. The research group consisted of 95 English teachers who study in secondary school in Duzce in 2013-2014. Survey method was used and quantitative data were used. Language teaching methods scale developed by researcher was practiced to define which methods English teachers use. As a result, it was seen that teachers used Grammar Based Method at a high level and used Speaking Based Method at a low level. As a result of statistics, it was seen that methods changed according to gender, seniority and graduated school types.
\end{abstract}

Keywords Language Teaching Method, Gender, Seniority, Graduated School Type

\section{Introduction}

Communication among different nations became very important in our increasingly shrinking world in terms of globalization. Today communication is done multi-dimensional and in different types [1]. In world, nowadays, we live knowledge era, language is the most important key of lifelong learning and development. Actions such as reading, writing, thinking, solving problem, criticizing, and understanding occur with language. Language is the basic tool of development in terms of social, mental and sensitive. Language has an important place in processes such as communicating, explaining emotions and opinions, integration with world, cultural connection and interaction. Characteristics such as developing capacity of people, solving complicated problems, thinking scientific, having different values, wide worldview are effected by language. This situation shows us that language skills should be developed lifelong and shouldn't be limited with school education. So many countries give importance to using new approaches and methods to develop language skills [2].

For centuries, people have attempted to learn foreign/second languages through formal education. The methods and approaches employed have changed through the years, having been impacted by advancements in the theories and psychology of learning [3].

"Language teaching has a long, fascinating but rather tortuous history, in which a debate on teaching methods has evolved particularly over the last hundred years. The names of many of the methods (Grammar-Translation Method, Direct Method, Audio-lingual Method, Communicative Teaching Method, etc) are familiar enough, yet the methods are not easy to grasp in practice because a method, however ill-defined it may be, is more than a single strategy or a particular technique. As a part of language teaching theories, these methods derived partly from social, economic, political, or educational circumstances, partly from theoretical consideration (new changes in language theories and in new psychological perspective on language learning), partly from practical experience, intuition, and inventiveness [4]."

Prior to this century, language teaching methodology vacillated between two types of approaches: one type of approach which focused on using a language (i.e., speaking and understanding), the other type which focused on analyzing a language (i.e., learning the grammatical rules). Both the Classical Greek and Medieval Latin periods were characterized by an emphasis on teaching people to use foreign languages. The classical languages, first Greek and then Latin, were used as Iingua francas. Higher learning was given only in these languages all over Europe. They were also used very widely in philosophy or religion, politics, and business. Thus, the educated elite became fluent speakers, readers, and writers of the appropriate classical language. We can assume that the teachers or tutors used informal and direct approaches to convey the form and meaning of the language they were teaching and that they used aural-oral techniques with no language 
textbooks per se, but rather a small stock of hand-copied written manuscripts of some sort, perhaps a few texts in the target language, or crude dictionaries that listed equivalent words in two or more languages side by side [5]. The 20th century was characterized by many changes and innovations in the field of language teaching ideologies. In the history of language teaching approaches and methods, there was a move away from methods that focus on writing and reading to methods that stronger concentrate on the skills speaking and listening [6].

\subsection{Language Teaching Methods}

In language teaching, methods were formed to remove deficiency and inadequate of methods that were used before. These studies contributed to teaching a foreign language and gave alternative methods. Foreign language teaching methods accepted by Department of Modern Languages Council of Europe and used widely are [7]:

\section{- Grammar-Translation Method \\ - Direct Method \\ - Natural Method \\ - Audio-Lingual Method \\ - Cognitive-Code Method \\ - Communicative Method \\ - Eclectic Method}

The other methods used alternatively and less widely are:

- Suggestopedia

- Community Language Learning

- The Silent Way

- Total Physical Response

- Audiovisual Method

- Task-Based Method

- Content-Based Method

In Turkey, Direct Method was tried to using in language teaching but it was seen that students learned only basic sentences in 1919. Grammar-Translation Method was used in foreign language teaching from constitutional monarchy to republic. Because aim defines methods, education in language teaching was centered reading-understanding and translation so Grammar-Translation Method was used until 1941 and after. Then Direct Method was tried to using in language teaching again between 1944 and 1952 and books were organized according to this method. In 1966 Auido-Lingual Methods was used in teaching of both English and French. Universities were also just like other education instutions [8].

There are a lot of suggesstions and arguments about language teaching. Although there are a lot of researches about the factors effecting learning foreign language, there isn't enough research about teaching in Turkey. Curriculum suggests teacher how and which methods should be used for which aims. But there is no research about the level of usage. So in this research it was focused on it.

\subsection{Aim of Research}

The aim of this research is to define language teaching methods used by English teachers in Turkey and their usage level and to define if level of usage changes according to gender, seniority and graduated school types. In this context, questions below will be answered:

1. What is the level of usage of language teaching methods?

2. Does the level of usage of language teaching methods change according to gender, seniority and graduated school types?

\subsection{Importance of Research}

Throughout the history, a lot of methods were revived. Linguists offered different methods. Because the aim of language teaching changed and it was claimed that previous one was inadequate. It is known that the level of foreign language is so low in our country. If one of the most important factor in achieving education's aim is method, it should be defined what teachers do in class and which language teaching methods they use. In this research, thinking that linguists offered language teaching methods it was defined which language teaching methods teachers use and it was researched usage of methods according to gender, seniority and graduated school types. In this regard, this research will show the availability of our curriculum.

\section{Research Design and Methodology}

\subsection{Research Model}

The aim of the survey method is to describe the situation of the research subject. In this kind of research, relations between variables can be measured [9]. So survey method was used and quantitative data were used.

\subsection{Sample}

The research group consisted of 95 English teachers who study in secondary school in Duzce in 2013-2014 teaching year. In this research, it is aimed to reach all English teachers in Duzce.

\subsection{Data Collection Tools}

Scale developed by researcher was used to define language teaching methods that teacher use [10]. Authority view was applied, plot implementation was done, confirmatory and exploratory factor analysis were done to provide the validity of scale. Cronbach Alpha reliability value was calculated as .80 . Scale was consisted of five factors. Total variance explained by five factors was calculated as $54.69 \%$. Confirmatory factor analysis results confirmed the form of five factors. Factors were named as "Active Teaching Method, Listening Based Teaching Method, Four Basic Skills Focused Method, Speaking Based Method, and Grammar Based Method". While factors were being named, items in each factor were reviewed and according to common features of items in a factor, items were named. 
Table 1. The Result of Normalcy Test

\begin{tabular}{c|ccc|ccc}
\hline & \multicolumn{3}{|c|}{ Kolmogrov-Smirnov } & \multicolumn{3}{c}{ Shapiro-Wilk } \\
\hline & Statistic & sd & p & Statistic & sd & p \\
\hline Active Teaching Method &, 250 & 93 &, 000 &, 597 & 900 & 93 \\
Listening Based Teaching Method &, 200 & 93 &, 000 &, 922 &, 03 &, 000 \\
Four Basic Skills Focused Method &, 323 & 93 &, 000 &, 696 &, 03 &, 000 \\
Speaking Based Method &, 285 & 93 &, 000 &, 867 &, 03 &, 000 \\
Grammer Based Method &, 375 & 93 &, 000 &, 486 & 93 &, 000 \\
\hline
\end{tabular}

\subsection{Data Collection}

After permission was obtained from Duzce Provincial Directorate for National Education, "Language Teaching Methods Scale" was filled by 95 English teachers who study in secondary school in Duzce in 2013-2014 teaching year. Scale was given by researcher to teachers who study in center schools. But scale was sent by District Public Education with official letter to teachers who study in district schools.

\subsection{Analysis of Data}

Scale developed by researcher was used to define language teaching methods that teacher use. Oxford [11] evaluated Scale of Language Learning Strategies in three section such as "high level strategy usage $(3,50-5,00)$ ", " middle level strategy usage $(2,50-3,49)$ " and "low level strategy usage $(1,00-2,49)$ considering the average of answers. Also in this research, results were evaluated in three section such as "high level method usage $(3,50-5,00)$ ", " middle level method usage $(2,50-3,49)$ " and " low level method usage $(1,00-2,49)$

Normalcy test was done before starting analysis. Result of test was shown in Table 1.

If " $n$ " is 30 and above, "Kolmogrov-Smirnov" test should be done in normalcy tests [12]. "p" value should be above ,050 to understand if distribution is normal. According to this, when we look Table 1, it is seen that test result is $\mathrm{p}=, 000$ for all variables. That is, data hasn't got normal distribution. For this reason, Mann-Whitney U test was done to define if there were differences between methods and gender and graduated school type, Kruskal-Wallis test was done to define if there were differences between methods and seniority.

\section{Results}

\subsection{Results of First Sub-Problem}

Language teaching methods that teacher use were given with arithmetic mean and standard deviation.

\subsubsection{Usage of Active Teaching Method}

Active Teaching Method consisted of 6 items. Answers given by teachers were observed and results were presented in Table 2.
Table 2. Usage of Active Teaching Method

\begin{tabular}{ccccc}
\hline $\begin{array}{c}\text { Item } \\
\text { No }\end{array}$ & Item & $\mathrm{N}$ & $\chi$ & $\mathrm{SS}$ \\
\hline 1 & I place games in exercises & 95 & 1.83 & .76 \\
\hline 2 & $\begin{array}{c}\text { I use technique forming active } \\
\text { memory }\end{array}$ & 95 & 1.75 & .88 \\
\hline 3 & I benefit visual materials. & 95 & 1.85 & .89 \\
\hline 4 & $\begin{array}{c}\text { I benefit principals of arts such as } \\
\text { dram, music, imaging, painting etc. }\end{array}$ & 95 & 1.76 & .83 \\
\hline 5 & $\begin{array}{c}\text { I use gestures and facial } \\
\text { expressions actively. }\end{array}$ & 94 & 1.82 & .94 \\
\hline 6 & $\begin{array}{c}\text { I choose texts that is suitable for } \\
\text { making visual. I make texts } \\
\text { understood easily with visuals after } \\
\text { every sentence }\end{array}$ & 95 & 1.70 & .92 \\
\hline Mean: & $1.78 \quad$ & & \\
\hline
\end{tabular}

In Table 2, it is seen that arithmetic mean of teachers' answers is 1.78 . Because this mean is between 1.00-2.49 used as a reference, it is defined that teachers use this method at "low level". 3. item "I benefit visual materials" has the highest mean (1.85). This result shows that if there is possibility of using or supplying visual materials, teacher will use them. 6. item "I choose texts that is suitable for making visual. I make texts understood easily with visuals after every sentence" has the lowest mean (1.70). This result shows that teachers don't use visual materials in reading activities.

\subsubsection{Usage of Listening Based Teaching Method}

Listening Based Teaching Method consisted of 6 items. Answers given by teachers were observed and results were presented in Table 3.

Table 3. Usage of Listening Based Teaching Method

\begin{tabular}{ccccc}
\hline $\begin{array}{c}\text { Item } \\
\text { No }\end{array}$ & Item & $\mathrm{N}$ & $\chi$ & $\mathrm{SS}$ \\
\hline 7 & I teach grammer rules with music. & 95 & 1.40 & .49 \\
\hline 8 & Students sit in the form of circle. & 95 & 1.29 & .52 \\
\hline 9 & $\begin{array}{c}\text { I use voice recorder in first course } \\
\text { and record only target language } \\
\text { sentences. }\end{array}$ & 94 & 1.17 & .37 \\
\hline 10 & $\begin{array}{c}\text { I use language laboratoy instead of } \\
\text { class. }\end{array}$ & 95 & 1.42 & .55 \\
\hline 11 & I don't give homework. & 95 & 2.43 & .70 \\
\hline 12 & $\begin{array}{c}\text { I start course with film or voice } \\
\text { prensentation. }\end{array}$ & 95 & 1.70 & .61 \\
\hline \multicolumn{4}{c}{ Mean: 1.57 } \\
\hline
\end{tabular}


In Table 3, it is seen that arithmetic mean of teachers' answers is 1.57. Because this mean is between 1.00-2.49 used as a reference, it is defined that teachers use this method at "low level". 11. item "I don't give homework." has the highest mean (2.43). This result shows that teachers don't give extra activity. 9. item "I use voice recorder in first course and record only target language sentences." has the lowest mean (1.17).

\subsubsection{Usage of Four Basic Skills Focused Method}

Four Basic Skills Focused Method consisted of 5 items. Answers given by teachers were observed and results were presented in Table 4.

Table 4. Usage of Four Basic Skills Focused Method

\begin{tabular}{ccccc}
\hline $\begin{array}{c}\text { Item } \\
\text { No }\end{array}$ & Item & N & $X$ & SS \\
\hline 13 & $\begin{array}{c}\text { In teaching, I take into } \\
\text { consideration mother tongue } \\
\text { learning turn (listening, speaking, } \\
\text { reading, writing). }\end{array}$ & 95 & 3.69 & 1.11 \\
\hline 14 & $\begin{array}{c}\text { My main aim is to teach the skills } \\
\text { of listening and speaking. }\end{array}$ & 95 & 4.02 & 1.08 \\
\hline 15 & $\begin{array}{c}\text { I take into consideation cultural } \\
\text { features of learner in choosing } \\
\text { text and dialogue. }\end{array}$ & 94 & 3.95 & 1.10 \\
\hline 16 & $\begin{array}{c}\text { I give importance to teaching of } \\
\text { four basic skills. }\end{array}$ & 95 & 3.84 & 1.28 \\
\hline 17 & $\begin{array}{c}\text { I teach all language skills to } \\
\text { communicate in natural context. }\end{array}$ & 95 & 3.93 & 1.11 \\
\hline \multicolumn{4}{c}{ Mean: 3.89 } \\
\hline
\end{tabular}

In Table 4, it is seen that arithmetic mean of teachers' answers is 3.89. Because this mean is between 3.50- 5.00 used as a reference, it is defined that teachers use this method at "high level". 14. item "My main aim is to teach the skills of listening and speaking." has the highest mean(4.02). The main aim of foreign language teaching is that students should speak, understand and communicate with each other in target language. This result shows that teachers have this consciousness. 13. item "In teaching, I take into consideration mother tongue learning turn (listening, speaking, reading, writing)." has the lowest mean (3.69). This result shows that although teachers give importance to teaching of speaking and listening, they disregard mother tongue learning turn in teaching process.

\subsubsection{Usage of Speaking Based Method}

Speaking Based Method consisted of 3 items. Answers given by teachers were observed and results were presented in Table 5 .

In Table 5 , it is seen that arithmetic mean of teachers' answers is 1.44 . Because this mean is between 1.00-2.49 used as a reference, it is defined that teachers use this method at "low level". 20. item "I make pronunciation exercises in last of the course." has the highest mean (1.46). this result shows that teachers give importance to teaching of speaking skill slightly. 19. item "As a teaching language, I use target language." has the lowest mean (1.41). According to this result teachers use mother tongue in the process of teaching.

Table 5. Usage of Speaking Based Method

\begin{tabular}{ccccc}
\hline $\begin{array}{c}\text { Item } \\
\text { No }\end{array}$ & Item & $\mathrm{N}$ & $\chi$ & $\mathrm{SS}$ \\
\hline 18 & I teach pronunciation. & 95 & 1.45 & .50 \\
\hline 19 & $\begin{array}{c}\text { As a teaching language, I use target } \\
\text { language. }\end{array}$ & 95 & 1.41 & .61 \\
\hline 20 & $\begin{array}{c}\text { I make pronunciation exercises in } \\
\text { last of the course. }\end{array}$ & 95 & 1.46 & .52 \\
\hline Mean: 1.44 & & & \\
\hline
\end{tabular}

\subsubsection{Usage of Grammar Based Method}

Grammar Based Method consisted of 3 items. Answers given by teachers were observed and results were presented in Table 6 .

Table 6. Usage of Grammar Based Method

\begin{tabular}{ccccc}
\hline $\begin{array}{c}\text { Item } \\
\text { No }\end{array}$ & Item & $\mathrm{N}$ & $\chi$ & $\mathrm{SS}$ \\
\hline 21 & $\begin{array}{c}\text { I write grammer rules on the board } \\
\text { and want students to write their } \\
\text { notebooks. }\end{array}$ & 95 & 4.67 & .65 \\
\hline 22 & $\begin{array}{c}\text { I make a word list including verbs, } \\
\text { nouns and adjectives. }\end{array}$ & 95 & 4.47 & .78 \\
\hline 23 & $\begin{array}{c}\text { I do grammer exercises in the last of } \\
\text { the course. }\end{array}$ & 95 & 4.62 & .80 \\
\hline Mean: 4,58 & & & \\
\hline
\end{tabular}

In Table 6, it is seen that arithmetic mean of teachers' answers is 4.58. Because this mean is between 3.50-5.00 used as a reference, it is defined that teachers use this method at "high level". 21. item "I write grammar rules on the board and want students to write their notebooks." has the highest mean (4.67). This shows that teachers teach grammar with classic methods instead of context. 22. item has the lowest mean (4.47). According to this result, teachers don't give importance to teaching of words in grammar teaching.

\subsection{Results of Second Sub-Problem}

In this section, it is searched that whether high level of language teaching method usage changes according to gender, seniority and graduated school types. Numerical data about the high level of usage of methods was presented in Table 7.

Table 7. Numerical Data about High Level of Usage of Language Teaching Methods

\begin{tabular}{ccc}
\hline & $\mathrm{n}$ & $\%$ \\
\hline Grammar Based Method & 20 & 21 \\
Grammer and Four Basic Skills Focused Method & 72 & 76 \\
Active and Four Basic Skills Focused Method & 3 & 3 \\
\hline Total & 95 & 100
\end{tabular}

Mann-Whitney $U$ test was done to define whether there was a difference between gender and methods used. The difference between gender and methods is presented in 
Table 8 .

Table 8. The Result of Mann-Whitney U Test About Difference Between Gender and Grammar Based Method

\begin{tabular}{cccccc}
\hline & $\mathrm{N}$ & $\begin{array}{c}\text { Rank } \\
\text { Mean }\end{array}$ & $\begin{array}{c}\text { Rank } \\
\text { Total }\end{array}$ & $\mathrm{U}$ & $\mathrm{p}$ \\
\hline Female & 74 & 50.94 & 3769.50 & 559.500 &, 006 \\
Male & 21 & 37.64 & 790.50 & & \\
\hline
\end{tabular}

As a result of Mann-Whitney $U$ test done to define whether there were a differences between gender and Grammar Based Method, it was seen that there was a meaningful difference (U:559.500; $\mathrm{p}<.05$ ). When mean rank is considered, female teachers' mean (X: 50.94) is higher than male teachers' mean (X:37.64). According to this result, it can be said gender is an important factor for the usage of Grammar Based Method.

Table 9. The Result of Mann-Whitney U Test About Difference Between Gender and Grammar and Four Basic Skills Focused Method

\begin{tabular}{cccccc}
\hline & $\mathrm{N}$ & $\begin{array}{c}\text { Rank } \\
\text { Mean }\end{array}$ & $\begin{array}{c}\text { Rank } \\
\text { Total }\end{array}$ & $\mathrm{U}$ & $\mathrm{p}$ \\
\hline Female & 74 & 44.06 & 3260.50 & 485.500 &, 000 \\
Male & 21 & 61.88 & 1299.50 & & \\
\hline
\end{tabular}

As a result of Mann-Whitney $U$ test done to define whether there was a difference between gender and Grammar and Four Basic Skills Focused Method, it was seen that there was a meaningful difference (U:485.500; $\mathrm{p}<.05)$. When mean rank is considered, female teachers' mean (X: 44.06) is lower than male teachers' mean (X: 61.88) According to this result, it can be said gender is an important factor for the usage of Grammar and Four Basic Skills Focused Method.

Table 10. The Result of Mann-Whitney U Test About Difference Between Gender and Active and Four Basic Skills Focused Method

\begin{tabular}{cccccc}
\hline & $\mathrm{N}$ & $\begin{array}{c}\text { Rank } \\
\text { Mean }\end{array}$ & $\begin{array}{c}\text { Rank } \\
\text { Total }\end{array}$ & $\mathrm{U}$ & $\mathrm{p}$ \\
\hline Female & 74 & 48.86 & 3615.50 & 713.500 &, 060 \\
Male & 21 & 44.98 & 944.50 & & \\
\hline
\end{tabular}

As a result of Mann-Whitney $U$ test done to define whether there was a difference between gender and Active and Four Basic Skills Focused Method, it was seen that there was no difference (U:713.500; $\mathrm{p}>.05$ ).

Mann-Whitney U test was done to define whether there was a difference between graduated school types and methods used. The difference between graduated school types and methods is presented in Table 11 .

Table 11. The Result of Mann-Whitney U Test About Difference Between Graduated School Types and Grammar Based Method

\begin{tabular}{cccccc}
\hline & $\mathrm{N}$ & $\begin{array}{c}\text { Rank } \\
\text { Mean }\end{array}$ & $\begin{array}{c}\text { Rank } \\
\text { Total }\end{array}$ & $\mathrm{U}$ & $\mathrm{p}$ \\
\hline $\begin{array}{c}\text { Faculty of } \\
\text { Education }\end{array}$ & 75 & 50.40 & 3780.00 & 570.000 & .020 \\
$\begin{array}{c}\text { Faculty of } \\
\text { Arts and } \\
\text { Science }\end{array}$ & 20 & 39.00 & 780.00 & & \\
\hline
\end{tabular}

As a result of Mann-Whitney $U$ test done to define whether there was a difference between graduated school types and Grammar Based Method, it was seen that there was a meaningful difference (U:552,500; $\mathrm{p}<.05)$. When mean rank is considered, Faculty of Education's mean (X: 50.94) is higher than Faculty of Arts and Science's mean (X:39.00) According to this result, it can be said graduated school types is an important factor for the usage of Grammar Based Method.

Table 12. The Result of Mann-Whitney U Test About Difference Between Graduated School Types and Grammer and Four Basic Skills Focused Method

\begin{tabular}{lccccc}
\hline & $\mathrm{N}$ & $\begin{array}{c}\text { Rank } \\
\text { Mean }\end{array}$ & $\begin{array}{c}\text { Rank } \\
\text { Total }\end{array}$ & $\mathrm{U}$ & $\mathrm{p}$ \\
\hline $\begin{array}{l}\text { Faculty of } \\
\text { Education }\end{array}$ & 75 & 45.87 & 3440.00 & 590.000 &, 046 \\
\hline
\end{tabular}

As a result of Mann-Whitney $U$ test done to define whether there was a difference between graduated school types and Grammar and Four Basic Skills Focused Method, it was seen that there was a meaningful difference (U:590.000; p<.05). When mean rank is considered, Faculty of Education's mean (X: 45.87) is lower than Faculty of Arts and Science's mean (X: 56.00). According to this result, it can be said graduated school types is an important factor for the usage of Grammar and Four Basic Skills Focused Method.

Table 13. The Result of Mann-Whitney U Test About Difference Between Graduated School Types and Active and Four Basic Skills Focused Method

\begin{tabular}{cccccc}
\hline & $\mathrm{N}$ & & $\begin{array}{c}\text { Rank } \\
\text { Total }\end{array}$ & $\mathrm{U}$ & $\mathrm{p}$ \\
\hline $\begin{array}{c}\text { Faculty of } \\
\begin{array}{c}\text { Education } \\
\text { Faculty of } \\
\text { Arts and }\end{array}\end{array}$ & 75 & 47.60 & 3570.00 & 720.000 &, 366 \\
Science & 20 & 49.50 & 990.00 & & \\
\hline
\end{tabular}

As a result of Mann-Whitney $U$ test done to define whether there was a difference between graduated school types and Active and Four Basic Skills Focused Method, it was seen that there was no difference (U:720.000; $p>.05$ ).

Kruskal Wallis test was done to define whether there was a difference between seniority and methods used. The difference between seniority and methods is presented in Table 14.

Table 14. The Result of Kruskal Wallis Test About the Usage of Grammar Based Method in Terms of Seniority

\begin{tabular}{cccccc}
\hline & $\mathrm{N}$ & $\begin{array}{c}\text { Rank } \\
\text { Mean }\end{array}$ & sd & $X^{2}$ & $\mathrm{p}$ \\
\hline 0-5 year & 36 & 42.17 & & & \\
6-10 year & 37 & 47.73 & & & \\
11-15year & 17 & 58.00 & 3 & 9.044 & .029 \\
16-up year & 5 & 58.00 & & & \\
\hline
\end{tabular}


As a result of Kruskal Wallis test done to define whether there was a difference between seniority and Grammar Based Method, it was seen that there was a meaningful difference $\left(X^{2}: 9.044, \mathrm{sd}: 3, \mathrm{n}: 95, \mathrm{p}<.05\right)$. According to this, it can be said the usage of Grammar Based Method was affected by seniority. When mean rank is considered, teachers' means whose seniority is between 0-5 year (X: 42.17) and between 6-10 year (X: 47.73) are lower than teachers' mean whose seniority is between 11-up year (X:58.00). According to this result, it can be said that seniority is an important factor for the usage of Grammar Based Method.

Table 15. The Result of Kruskal Wallis Test About the Usage of Grammar and Four Basic Skills Focused Method in Terms of Seniority

\begin{tabular}{cccccc}
\hline & $\mathrm{N}$ & $\begin{array}{c}\text { Rank } \\
\text { Mean }\end{array}$ & sd & $X^{2}$ & $\mathrm{p}$ \\
\hline 0-5 year & 36 & 54.15 & & & \\
6-10 year & 37 & 47.27 & & & \\
11-15year & 17 & 37.00 & 3 & 8.504 & .037 \\
16-up year & 5 & 46.50 & & & \\
\hline
\end{tabular}

As a result of Kruskal Wallis test done to define whether there was a difference between seniority and Grammar and Four Basic Skills Focused Method, it was seen that there was a meaningful difference $\left(X^{2}: 8.504, \mathrm{sd}: 3, \mathrm{n}: 95, \mathrm{p}<.05\right)$. According to this, it can be said the usage of Grammar and Four Basic Skills Focused Method was affected by seniority. When mean rank is considered, teachers' means whose seniority is between 0-5 year (X: 54.15) are higher than teachers' means whose seniority is between 6-10 year (X: 47.27), 11-15year (X: 37.00) and 16-up year (X:46.50). According to this result, it can be said that seniority is an important factor for the usage of Grammar and Four Basic Skills Focused Method.

Table 16. The Result of Kruskal Wallis Test About the Usage of Active and Four Basic Skills Focused Method in Terms of Seniority

\begin{tabular}{cccccc}
\hline & $\mathrm{N}$ & $\begin{array}{c}\text { Rank } \\
\text { Mean }\end{array}$ & $\mathrm{sd}$ & $X^{2}$ & $\mathrm{p}$ \\
\hline 0-5 year & 36 & 46.86 & & & \\
6-10 year & 37 & 49.50 & & &, 072 \\
11-15year & 17 & 49.50 & 3 & 7.001 & \\
16-up year & 5 & 40.00 & & & \\
\hline
\end{tabular}

As a result of Kruskal Wallis test done to define whether there was a difference between seniority and Active and Four Basic Skills Focused Method, it was seen that there was a meaningful difference $\left(X^{2}: 7.001, \mathrm{sd}: 3, \mathrm{n}: 95, \mathrm{p}>.05\right)$. According to this result, it can be said that seniority is not an important factor for the usage of Active and Four Basic Skills Focused Method.

\section{Conclusion and Discussion}

\subsection{Conclusion and Discussion of First Sub-problem}

In first sub-problem of this research, it is searched that what the level of usage of language teaching methods is. According to results:

When sub-factors of scale were observed, it was seen that Grammar Based Method had the highest mean. This result shows teachers didn't give up traditional methods and teach foreign language based grammar. This result supports Akdoğan's [13] research. In his research Akdoğan asked 120 teachers and faculty members " Which one is mostly used in Turkey?" and they pointed out 112 times Grammar Translation Method, 65 times Direct Method and less than 10 times other methods. As a result, it can be said that although it is accepted this method is inadequate, in our country Grammar Translation Method is used mostly. Opportunities that will provide teachers' personal and occupational developments should be presented to teachers. Teachers should follow developments about language teaching in world and accept that language is not a set of rule. Karaman [14] searched about abroad experiences of prospective teachers and found that abroad experiences improved teachers language development, awareness and professionalism. Both world view and social interaction in abroad was so important in teachers' experiences. It can be said that if there is an opportunity of abroad experience for English teachers, it will change teachers' thoughts about language.

Because communication is forefront in teaching of living languages, Grammar Translation Method is insufficient. As all rules of language are given in the beginning, mother tongue is used and aim is to translate correctly [15].

New English Curriculum was introduced in academic year 2013-2014 Turkey. Although this curriculum supports mixed methods, it is developed basically Communicative Method. Communicative method highlights teaching four basic language skills (speaking, listening, reading, writing) in a context and as a whole. It is suggested that teachers should choose materials directing students' five sense expect of books. Teaching is student centered. So students release teachers' pressure. This situation gives opportunities to using language, taking responsibility in a grup, doing something together, developing personality [16].

\subsection{Conclusion and Discussion of Second Sub-Problem}

In second sub-problem of this research, it is searched that whether high level of usage of methods changes according to gender, seniority, graduated school types. According to results:

There is a difference between gender and teachers using Grammar Based Method. Female teachers' arithmetic mean is more than male teachers' arithmetic mean. Also there is 
difference between gender and Grammar and Four Basic Skills Focused Method Based Method. Male teachers' arithmetic mean is more than female teachers' arithmetic mean. But there is no difference between gender and Four Basic Skills Focused and Active Teaching Method. As a reason it can be said that the number of teachers using these methods is so low. As a result it can be said gender is effective on choosing method. This situation supports Kılıç [17]. In his research Kılıç searched whether there were differences between gender and teaching style. As a result, his research there was no difference between gender and expert, personal, directive style. But gender was effective on authoritarian and representative style in favor of female.

There is a difference between seniority and teachers using Grammar Based Method. 11-above years teachers' arithmetic mean is more than others' arithmetic mean. Also there is difference between seniority and Grammar and Four Basic Skills Focused Method Based Method. 0-5 years teachers' arithmetic mean is more than others' arithmetic mean. But there is no difference between seniority and Four Basic Skills Focused and Active Teaching Method. As a reason it can be said that the number of teachers using these methods is so low. As a result it can be said seniority is effective on choosing method. But this situation is different from Kılıç's [17] research. In his research Kıliç searched whether there were differences between seniority and teaching style. As a result, in his research there was no difference between seniority and expert, personal, directive, authoritarian and representative style.

There is a difference between graduated school types and teachers using Grammar Based Method. This difference is in favor of Faculty of Education. Also there is difference between graduated school types and Grammar and Four Basic Skills Focused Method Based Method. This difference is in favor of Faculty of Arts and Sciences. But there is no difference between graduated school types and Four Basic Skills Focused and Active Teaching Method. As a reason it can be said that the number of teachers using these methods is so low. This situation supports Yaman [18]. In his research Yaman wanted teachers to evaluate the curriculum. As a result, it was seen that teachers graduated from English Language and Literature had negative thoughts about the aim, contents, process and evaluation of curriculum. But teachers graduated from Faculty of Education had positive thoughts about curriculum.

\section{Acknowledgements}

This research received no specific grant from any funding agency in the public, commercial, or not-for-profit sectors.

\section{REFERENCES}

[1] Tok, H. \& Arıbaş, S. Avrupa Birliğine Uyum Sürecinde Yabancı Dil Öğretimi. Journal of Education Faculty of Inonu University. 2008; 9(15), 205-227.

[2] Güneş, F. Dil Öğretim Yaklaşımları ve Türkçe Öğretimindeki Uygulamalar. Journal of Social Sciences of Mustafa Kemal University. 2011; 8(15) 123-148.

[3] Zainuddin et al. Methods/Approaches of Teaching ESOL: A Historical Overview. Kendall Hunt Publishing Co; 2011.

[4] Jin-fang, S. \& Qing-xue, L. An Analysis of Language Teaching Approaches and Methods- Effectiveness and Weakness. US-China Education Review. 2007; 4(1).

[5] Murcia, M. C. Teaching English As a Second or Foreign Language. Boston: Massachusetts: Heinle \& Heinle Publishers; 1991.

[6] Kamhuber, P. Comparison of Grammar in Austrianand Spanish English Language Teaching Textbooks. Lehramt Englisch. Bewegungund Sport. Wien; 2010.

[7] Memiş, M.R. \& Erdem, M. D. 2013. Yabancı Dil Öğretimde Kullanılan Yöntemler, Kullanım Özellikleri ve Eleştiriler. Turkish Studies- International Periodical For The Languages, Literature and History of Turkish or Turkic. [http://www.turkishstudies.net/Makaleler/321673399 026M emi\%c5\%9fMuhammetRa\%c5\%9fit-vd-297-318.pdf] Ankara, [cited 2013 April 10] 8/9, s: 297-318.

[8] Demircan, Ö. Dünden Bugüne Türkiye'de Yabanc1 Dil. İstanbul: Remzi Kitabevi; 1993.

[9] Büyüköztürk, Ş. Çakmak, E.K. Akgün, Ö. E. Karadeniz, Ş. \& Demirel, F. Bilimsel Araştırma Yöntemleri. Ankara: Pegem Akademi; 2013.

[10] Ökmen, B. İngilizce Öğretmenlerinin Kullandıkları Dil Öğretim Yöntemlerinin Öğrencilerin Akademik Başarısına Etkisi. Master Thesis. Duzce University. Duzce, 2015.

[11] Oxford, R. L. Language Learning Strategies: What Every Teacher Should Know. Boston: Heinle and Heinle; 1990.

[12] Seçer, İ. SPSS ve LISREL ile Pratik Veri Analizi. Ankara: Anı Yayınc1lı; 2013.

[13] Akdoğan, S. Türkiye'de Yabancı Dil Öğretiminde Karşılaşılan Sorunlar ve Bir Çözüm Önerisi Olarak Yabancı Dil Okullarına Yönelik Öğretmen ve Öğretim Elemanlarının Görüşleri. Master Thesis, Fırat University. Institute of Social Sciences. Elazı̆̆, 2010.

[14] Karaman, A. C. Systems Thinking for Studying International Professional Program Participants' Thoughts. SystPract Action Res, 2009; 23, 203-220.

[15] Tosun, C. Yabancı Dil Öğretim ve Öğreniminde Eski ve Yeni Yöntemlere Yeni Bir Bakış. Journal of Arts and Sciences, Çankaya University, Faculty of Art and Literature, 2006; 5.

[16] Aktaş, T. Yabancı Dil Öğretiminde İletişimsel Yeti. Journal of Language and Linguistic Studies. 2005; 1(1).

[17] Kılıç, G. İlköğretim 6. sınıf Öğrencilerinin Öğrenme Biçemleri ile İlköğretim Okullarında Görevli İngilizce Öğretmenlerinin Öğrenme ve Öğretme Biçemlerinin Belirlenmesi. Master Thesis, Ankara University. Ankara, 2011. 
[18] Yaman, S. İlköğretim Birinci Kademe İngilizce Dersi Öğretim Programının Öğretmen Görüşlerine Göre
Değerlendirilmesi. Master Thesis, Furat University, Institute of Social Sciences. Elazı $\breve{g}, 2010$. 